\title{
Impact of minimum support price scheme for cotton and maize in North Karnataka
}

\section{MURTHY, BOURAMMA P. KERUR AND VILAS KULKARNI}

\begin{abstract}
MSP is a form of market intervention by the Government of India to insure agricultural producers against any sharp fall in farm prices to protect the producer- farmers- against excessive fall in price during bumper production years. The effectiveness of Price Policy at the state level involves the availability of market infrastructure at the state level and the initiative taken by the State Governments to create an institutional structure for monitoring agricultural prices. The study was conducted during the year 2014-15 using the secondary data pertaining to the MSP for different crops and open market prices for cotton and maize in selected markets of Dharwad and Haveri. Compound growth rates were computed to comprehend the annual growth in MSP of agricultural commodities for the period from 2000-01 to 2014-15. It is revealed that revealed that the annual growth rates for MSP for all commodities were found to be positive and significant except barley. The growth rate of MSP for maize and cotton were 8.74 per cent and 6.81 per cent, respectively. The increase in MSP was not equitable to all the crops. Both open market prices and MSP shown increasing trend but most of the years, open market prices for both cotton and maize were higher than the Minimum Support Prices in all the selected markets of Dharwad and Haveri and the percentage differences were not high. The influence of MSP on market price was not significant in cotton and maize. Hence, there is need to bring some improvement in the price policy to different crops in ensuring highest returns to the farmers to continue their production with the increase in cost of inputs especially the crops like cotton and maize.
\end{abstract}

KEY WORDS : Minimum support, Price scheme, Cotton, Maize

How to cite this paper : Murthy, C., Kerur, Bouramma P. and Kulkarni, Vilas (2015). Impact of minimum support price scheme for cotton and maize in North Karnataka. Internat. J. Com. \& Bus. Manage, 8(2) : 153-161. INDIA 